\title{
PHYSICAL AND MECHANICAL PROPERTIES OF JUVENILE Schizolobium amazonicum WOOD ${ }^{1}$
}

Graziela Baptista Vidaurre ${ }^{2 *}$, Benedito Rocha Vital ${ }^{3}$, Angélica de Cássia Oliveira ${ }^{3}$, José Tarcísio da Silva Oliveira $^{2}$, Jordão Cabral Moulin ${ }^{4}$, João Gabriel Missia da Silva ${ }^{5}$ and Denise Ransolin Soranso ${ }^{5}$

\footnotetext{
${ }^{1}$ Received on 15.07.2015 accepted for publication on 29.03.2017.

${ }^{2}$ Universidade Federal do Espírito Santo, Centro de Ciências Agrárias, Jerônimo Monteiro, Espírito Santo - Brasil. E-mail: <grazividaurre@gmail.com> and <jtsilva@npd.ufes.br>.

${ }^{3}$ Universidade Federeal de Viçosa, Departamento de Engenharia Florestal, Viçosa, Minas Gerais - Brasil. E-mail: <bvital@ufv.br $>$ and $<$ cassiacarneiro@ufv.br>.

${ }^{4}$ Universidade Federeal de Lavras, Doutorado em Ciência e Tecnologia da Madeira, Brasil, Lavras, Minas Gerais - Brasil. E-mail: <jordao_cm@hotmail.com>.

${ }^{5}$ Universidade Federal do Espírito Santo, Programa de Pós-Graduação em Ciências Florestais, Espírito Santo - Brasil. E-mail:<j.gabrielmissia@hotmail.com> and $<$ denise_soranso@hotmail.com>.

*Corresponding author.
}

\begin{abstract}
Growth in world demand for wood implies a search for new fast growing species with silvicultural potential, and in this scenario for native species such as Paricá. Thus, the objective of this study was determining the physical and mechanical wood properties of the Schizolobium amazonicum species (known as Paricá in Brazil). Trees were collected from commercial plantations located in the north of Brazil with ages of 5, 7, 9 and 11 years. Four logs from trees of each age in the longitudinal direction of the trees were obtained, and later a diametrical plank of each log was taken to manufacture the specimens which were used to evaluate some physical and mechanical properties of the wood. The basic density of Paricá was reduced in the basetop direction and no difference between the radial positions was observed, while the average basic density of this wood was characterized as low. The region close to the bark showed less longitudinal contraction and also greater homogeneity of this property along the trunk, while for tangential contraction the smallest variation was found in the region near the pith. Paricá wood contraction was characterized as low. Age influenced most of the mechanical properties, where logs from the base had the highest values of mechanical strength.
\end{abstract}

Keywords: Paricá, Wood density; Mechanical strength..

\section{PROPRIEDADES FÍSICAS E MECÂNICAS DA MADEIRA JUVENIL DE SCHIZOLOBIUM AMAZONICUM}

RESUMO-O crescimento da demanda mundial por madeira implica na busca de novas espécies de rápido crescimento com potencial silvicultural e, nesse cenário, as espécies nativas como o paricá. Assim, o objetivo deste trabalho foi determinar as propriedades fisicas e mecânicas da madeira da espécie Schizolobium amazonicum (paricá). As árvores foram coletadas em plantios comerciais localizados no norte do Brasil, com idades de 5, 7, 9 e 11 anos. Das árvores de cada idade foram obtidas quatro toras no sentido longitudinal das árvores e, posteriormente, um pranchão diametral de cada tora para fabricação dos corpos de prova, os quais foram utilizados para avaliar algumas propriedades fisicas e mecânicas da madeira. A densidade básica do paricá reduziu no sentido base-topo e não houve diferença entre as posições radiais, em média, a densidade básica dessa madeira caracterizou-se como baixa. A região próxima da casca apresentou menor contração longitudinal, e também, maior homogeneidade dessa propriedade ao longo do tronco, enquanto para a contração tangencial a menor variação foi encontrada na região próxima à medula. A contração da madeira de paricá foi caracterizada como baixa. A idade influenciou a maioria das propriedades mecânicas, tendo a tora da base os maiores valores de resistência mecânica.

Palavras-Chave: paricá, densidade da madeira, resistência mecânica. 


\section{INTRODUCTION}

In the past, wood supply derived from adult trees from native forests. Now, timber production in short cycles through adoption of fast growing species has become common due to the growing demand, thus modifying the practices of silvicultural management in plantations and increasing the researchers' interest regarding the characteristics and properties of wood at young ages (Lara Palma and Ballarin, 2003).

Juvenile wood is characterized for having great variability among its characteristics and anatomical, physical and mechanical properties (Bendtsen, 1978; Yeh et al., 2006; Guler et al., 2007). Recent scientific articles address the technological characteristics of juvenile wood in hardwoods, stressing the need for more knowledge about the properties of this material and its consequences on the generated products (Dünisch et al., 2010; Vidaurre et al., 2011; Peres et al., 2012; Cobas et al., 2013).

In Brazil, native species are little cultivated in a commercialized manner, as forests planted with exotic species predominate such as eucalyptus and pinus. Until a few decades ago, there were no forests planted in the Amazon region. However, an increase in world demand for wood has led to a search for new fast growing species with forestry potential, and in this scenario native species are generally advantageous regarding their adaptability.

The native Amazonian species Schizolobium amazonicum, known as Paricá, has been cultivated in the country for industrial purposes since the 1990s, mainly due to its rapid growth and cylindrical stem, which facilitates the manufacture of plywood. Its average logging age is only 7 years, with a high yield in lamination (around $80 \%$ ) due to the small amount of defects present in the wood (Vidaurre et al., 2006). Combined with the natural advantages of the species, development of appropriate technologies for Paricá lamination aroused interest in large-scale plantations. There are 90,047 hectares of Paricá trees planted in Brazil (Indústria Brasileira de Árvores - IBÁ, 2016).

Despite the increase in areas planted with Paricá trees, studies focusing on its wood properties are still scarce, especially considering different ages and positions in the trunk, which are important to evaluate the wood potential for different applications and consequently increase the use of this species. This paper describes the influence of age and sampling positions from pith to bark (pith-bark) and from the base to the top (base-top) directions in the physical and mechanical properties of Paricá wood.

\section{MATERIALAND METHODS}

The material used was obtained from commercial plantations with ages of 5, 7,9 and 11 years from companies located in the state of Pará, Brazil. The 5year plantation was located in the municipality of Itinga do Maranhão - MA (Latitude: 04 ${ }^{\circ} 40^{\prime}$ and longitude: $\left.47^{\circ} 36^{\prime}\right)$, the 7 -year plantation in the region of Dom Eliseu - PA (Latitude: $04^{\circ} 12^{\prime}$ and longitude: $47^{\circ} 27^{\prime}$ ) and the 9 and 11 -year plantations were located in the municipality of Paragominas - PA(Latitude: $02^{\circ} 48^{\prime}$ and longitude: $47^{\circ} 25^{\prime}$ ). All four plantations had $4 \times 4 \mathrm{~m}$ spacings between the trees. The climate of the regions is humid mesothermic, with average annual temperatures around $25^{\circ} \mathrm{C}$, and precipitation between 2,250 and 2,500 $\mathrm{mm}$. Despite being regular, the rain is concentrated from January to June (about $80 \%$ ), and the relative humidity is around $85 \%$. The seeds of these plantations came from the state of Mato Grosso, Brazil.

Four trees of each age with a mean settlement diameter were randomly selected in such a way that the selected individuals were representative. The trees were felled and sectioned into $2.7 \mathrm{~m}$ length logs obtaining four logs per tree, composing a sample from base-top direction and identified with numbers 1, 2, 3 and 4, with one representing the log from the base and then the logs obtained above the previous one in sequence. Only the first three logs were used for determining mechanical properties due to limitations regarding the dimensions of the fourth $\log$ from removing the specimens.

A diametric bord approximately $8 \mathrm{~cm}$ thick and width corresponding to the log diameter was removed from each log and used in preparing the specimens for all physical-mechanical analyzes. Samples for evaluation of the physical properties of the wood were removed from the pith-bark direction, where 4 were from the region near pith, and 4 from the region near the bark (corresponding the total width of the piece) for each one of the planks removed from the basetop direction of the trees, totaling 512 samples (4 ages $\mathrm{x} 4$ trees/age $\mathrm{x} 4$ planks/tree $\mathrm{x} 2$ sampling regions/plank $\mathrm{x} 4$ samples/region). The evaluated wood properties were basic density, linear and volumetric contractions and the anisotropic factor of the wood, according to NBR7190 (ABNT, 1997).

Revista Árvore. 2018;42(1):e420101 
Static flexion (resistance, tension at the proportionality limit and modulus of elasticity), resistance to parallel compression, parallel and perpendicular traction to the fibers, shearing and splitting, and Janka hardness were also determined in the three cutting planes. Four specimens were prepared per diametric board for each mechanical test, with a total of 192 samples ( 4 ages $\times 4$ trees/age $\mathrm{x} 3$ boards/tree $\mathrm{x}$ samples/board $\mathrm{x} 2$ conditions of humidity). The tests were performed with green wood and in equilibrium with the environment (around 13.3\%), in a universal machine with a maximum capacity of 100 $\mathrm{KN}$. All mechanical strengths of the air-dried wood were corrected for the standard reference condition of $12 \%$ moisture, as recommended by NBR7190 (ABNT, 1997).

The results were interpreted with the aid of analysis of variance (ANOVA), verifying the effect of age and sampling positions (pith-bark and base-top) and the interactions, and the Tukey test at 5\% significance level was applied when significant differences were found. For physical properties, the ages $(5,7,9$ and 11 years), the pith-bark (two regions) and base-top positions ( $\operatorname{logs} 1,2,3$ and 4$)$ were considered, while only the ages $(5,7,9$ and 11 years $)$ and the base-top positions $(\operatorname{logs} 1,2$ and 3$)$ were considered for the mechanical properties.

\section{RESULTS}

\subsection{Wood physical properties}

No effects of the pith-bark sampling positions were observed for basic wood density nor was there interaction of this factor with the ages and base-top positions. Thus, the mean basic density in the pithbark direction was equal to $0.280 \mathrm{~g} \mathrm{~cm}^{-3}$. A significant interaction was observed between the base-top positions and ages, meaning that the basic density behavior changed at different ages according to base-top positions (Table 1). A significant difference in basic density was only observed between the ages for base $\operatorname{logs}(\log 1)$, which was smaller for the age of 5 years. Base logs' densities were superior to the others, except for the age of 5 years which had homogeneity among the values of this property throughout the trunk. The interaction between the three factors (pith-bark positions, basetop positions and ages) was not significant.

No significant interactions were observed between age, pith-bark and base-top positions for linear and volumetric contractions, or anisotropic wood factor.
Table 1 - Variation of basic density in relation to ages and base-top sampling positions of Schizolobium amazonicum wood.

Tabela 1 - Variação da densidade básica em relação à idades e posições de amostragem base-topo da madeira de Schizolobium amazonicum.

\begin{tabular}{ccccc}
\hline \multirow{2}{*}{$\begin{array}{c}\text { Age } \\
\text { (years) }\end{array}$} & \multicolumn{4}{c}{ Basic Density $\left(\mathrm{g} \mathrm{cm}^{-3}\right)$} \\
Base-top positions \\
\hline 5 & $0.260 \mathrm{Ba}^{*}$ & $0.250 \mathrm{Aa}$ & $0.250 \mathrm{Aa}$ & $0.280 \mathrm{Aa}$ \\
7 & $0.320 \mathrm{Aa}$ & $0.280 \mathrm{Ab}$ & $0.280 \mathrm{Ab}$ & $0.270 \mathrm{Ab}$ \\
9 & $0.310 \mathrm{Aa}$ & $0.270 \mathrm{Ab}$ & $0.260 \mathrm{Ab}$ & $0.260 \mathrm{Ab}$ \\
11 & $0.360 \mathrm{Aa}$ & $0.270 \mathrm{Ab}$ & $0.280 \mathrm{Ab}$ & $0.290 \mathrm{Ab}$ \\
\hline
\end{tabular}

* Means followed by the same capital letter along the same column or by the same lowercase letter along the same line do not differ from each other by the Tukey test at $5 \%$ significance.

Also, no interactions between ages and sampling positions were found for all these properties, whether considering base-top or pith-bark directions. The only significant interactions occurred between the pith-bark and base-top positions for the longitudinal and tangential contraction properties. The remaining properties were evaluated separately, when there was a significant influence of a given factor.

The pith-bark direction was the only factor that significantly influenced all contractions and the anisotropic Paricá wood factor [Figure 1 (A)]. The age of the tree only affected longitudinal contractions, in which 9 and 11-year-old woods were more dimensionally stable [Figure 1 (B)]. The mean values of radial, tangential and volumetric contraction and the anisotropic factor of the wood for the four ages studied were $3.05 \%, 5.23 \%, 9.32 \%$ and 1.95 , respectively. No effects of the base-top positions on the radial and volumetric contractions and the anisotropic factor of the wood were found.

The longitudinal contractions in the region near the pith were larger in the lower parts of the trunk, in which the first two logs were statistically different from the others (Table 2). However, for this same region, the influence of trunk height on tangential contraction values was not verified. The influence of the pithbark direction was observed in the longitudinal contractions for logs 1 and 2, since the highest values of contraction occurred in the wood near the pith. The logs in the tangential plane with greater dimensional stability were generally those obtained from near the pith region. 
(A)

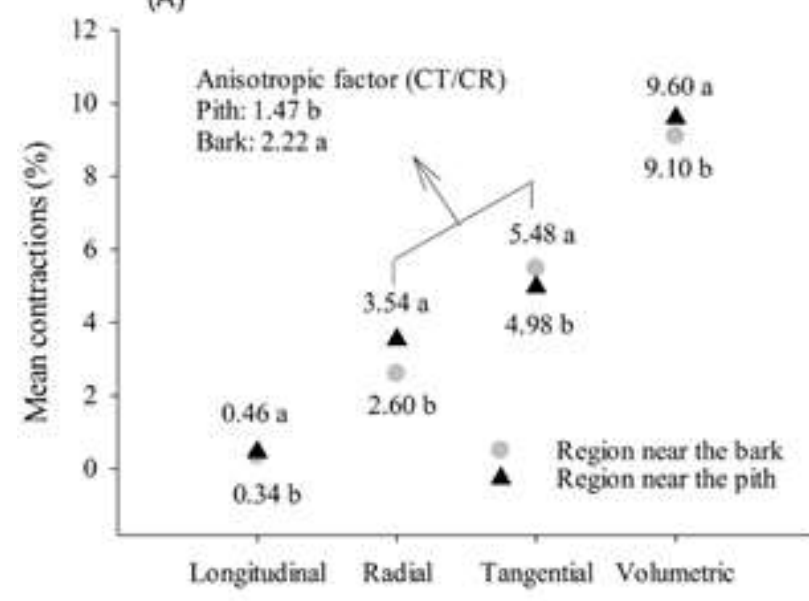

(B)

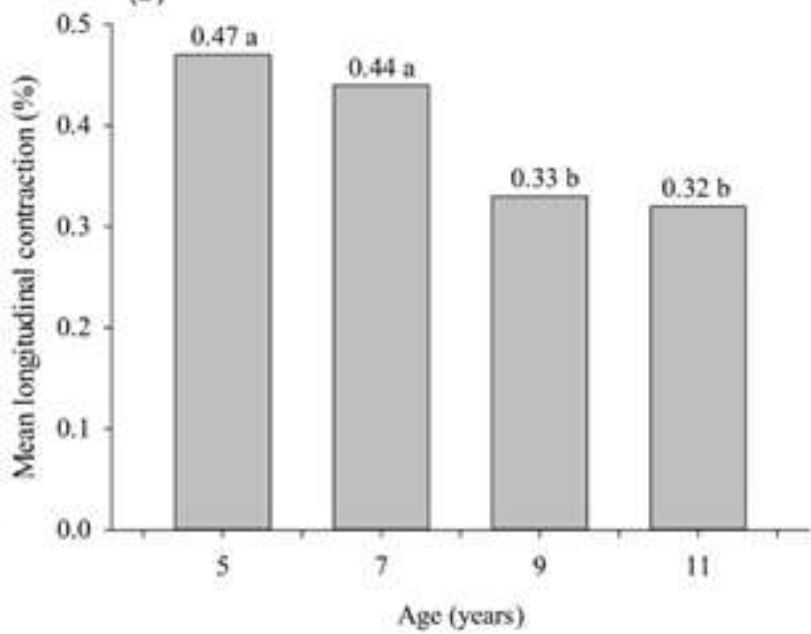

Figure 1 - Paricá wood pith-bark variation of contractions and anisotropic factor (A) and mean longitudinal contraction by age (B). Means followed by the same letter do not differ by Tukey test at $5 \%$ of significance.

Figura 1 -Variação medula-casca das contrações e fator anisotrópico (A) e contração longitudinal média por idade (B) da madeira de paricá. Médias seguidas pela mesma letra não diferem entre si pelo teste de Tukey a 5\% de significância.

Table 2 - Mean longitudinal and tangential contraction in relation to pith-bark and base-top positions of Paricá wood.

Tabela 2 - Contração longitudinal e tangencial média em relação as posições medula-casca e base-topo da madeira de paricá.

\begin{tabular}{lccc}
\hline \multirow{2}{*}{$\begin{array}{c}\text { Planes } \\
\text { positions }\end{array}$} & \multicolumn{2}{c}{$\begin{array}{c}\text { Pith-bark } \\
\text { positions }\end{array}$} \\
\cline { 3 - 4 } & & $\begin{array}{c}\text { Region } \\
\text { near the }\end{array}$ & $\begin{array}{c}\text { Region } \\
\text { near the }\end{array}$ \\
\hline \multirow{3}{*}{ Longitudinal } & $\mathbf{1}$ & $0.61 \mathrm{Aa} *$ & bark $(\%)$ \\
& $\mathbf{2}$ & $0.48 \mathrm{Aa}$ & $0.31 \mathrm{Ab}$ \\
& $\mathbf{3}$ & $0.34 \mathrm{Ba}$ & $0.30 \mathrm{Ab}$ \\
& $\mathbf{4}$ & $0.40 \mathrm{Ba}$ & $0.44 \mathrm{Aa}$ \\
\hline \multirow{3}{*}{ Tangential } & $\mathbf{1}$ & $4.69 \mathrm{Ab}$ & $5.77 \mathrm{Aa}$ \\
& $\mathbf{2}$ & $4.99 \mathrm{Ab}$ & $5.67 \mathrm{Aa}$ \\
& $\mathbf{3}$ & $5.13 \mathrm{Aa}$ & $5.39 \mathrm{Aa}$ \\
& $\mathbf{4}$ & $5.12 \mathrm{Aa}$ & $5.07 \mathrm{Bb}$ \\
\hline
\end{tabular}

* Averages followed by the same capital letter along the same column or by the same lowercase letter along the same line do not differ from each other by the Tukey test at $5 \%$ significance.

\subsection{Wood mechanical properties}

No significant interaction between ages and basetop sampling positions was found for any of the mechanical properties in wet (green) or dry (Table 3) conditions, thus the factors were evaluated separately.
The highest mechanical properties values were found for the age of 11 years in the air-dried wood. However, no effects of age were observed for tension at the proportionality limit (green), perpendicular traction (air-dried) or Janka radial hardness (green), tangential hardness (green and air-dried) or transverse hardness (green). In general, we could observe that the Janka hardness variable was the least influenced by tree age (Table 3).

Of the 22 mechanical properties studied (considering the two moisture conditions), the base-top positions only had significant effects on four properties, where the highest mean values were all recorded from base $\operatorname{logs}(\log 1)$ (Table 3). Shear strength (air dry) was similar between logs 2 and 3; and Janka radial hardness (green) had the lowest average value in $\log 2$, despite being significantly similar to $\log 3$, and not demonstrating a quali-quantitative reduction as the height of the tree increased as observed in the other properties.

The incremental percentage in the mechanical properties from the age of 5 to 11 years of age were not equal for all the studied properties and differed regarding the moisture condition of the wood (Table 4). Increasing the age of the trees from 5 to 11 years resulted in greater increases in mechanical properties, especially

Revista Árvore. 2018;42(1):e420101 
Table 3 - Effect of ages and base-top positions on the mechanical properties of Paricá wood in wet and dry conditions. Tabela 3 - Efeito das idades e posições base-topo nas propriedades mecânicas da madeira de paricá em condições úmidas

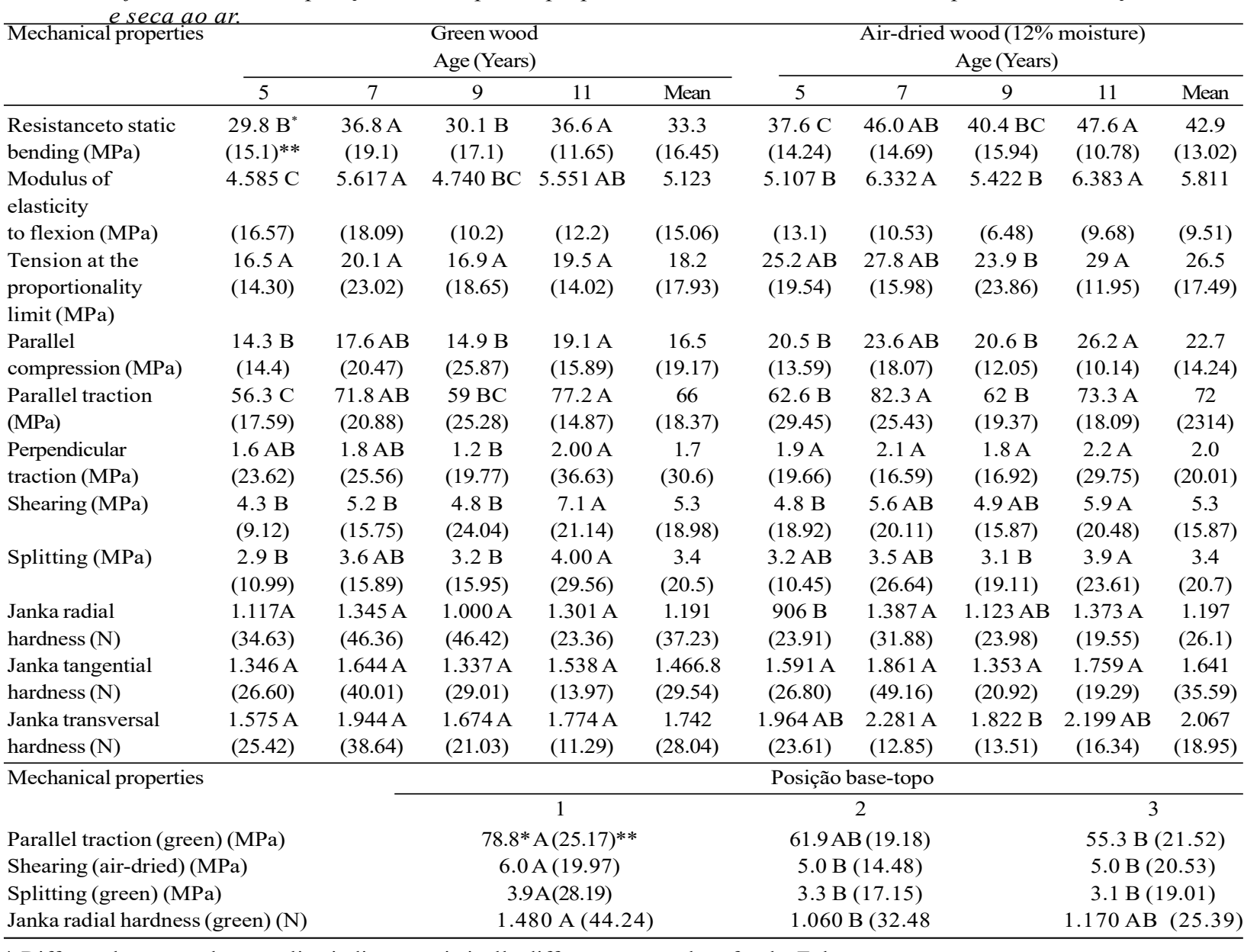

* Different letters on the same line indicate statistically different mean values for the Tukey test.

** Coefficient of variation (\%).

for wet samples, with special emphasis on shear strength. The greatest increase as a function of age for air-dried samples was for Janka hardness in the radial plane, followed by resistance to parallel traction and static bending.

\section{DISCUSSION}

\subsection{Physical properties}

According to the classifications suggested by Farmer (1972) considering the base-top positions simultaneously, Paricá wood at the ages of 5, 7 and 9 years is rated as exceptionally light, and at 11 years it is considered light; however, from 5 to 11 years, the increment of basic density in the base logs was
$27.8 \%$. The basic density values obtained for the age of 11 years were close to those found by Almeida et al. (2013), who obtained basic density of $0.30 \mathrm{~g} \mathrm{~cm}^{-3}$ in evaluating Paricá wood at 10 years of age coming from the state of Pará. On the other hand, Silva et al. (2013) found mean values of $0.34 \mathrm{~g} \mathrm{~cm}^{-3}$ for wood of species in native stands in the municipality of SinopMT at 15 years of age.

No effects of the pith-bark positions on basic density was observed for Paricá wood; however, new studies must be carried out with the purpose of evaluating density along the diameter using techniques such as X-ray densitometry. This technique will allow a micrometric description of wood density, since only two sampling positions were evaluated in this study. 
Table 4 - Superiority of mechanical resistance of Paricá wood at the age of 11 in relation to at 5 years (green and air-dried)

Tabela 4-Superioridade da resistência mecânica da madeira de paricá com idade de 11 anos em relação à de 5 anos (verde e seca ao ar).

\begin{tabular}{lcc}
\hline Mechanical properties & $\begin{array}{c}\text { \% of wood increasefrom } \\
5 \text { to } 11\end{array}$ \\
\cline { 2 - 3 } & $\begin{array}{c}\text { Green } \\
\text { wood }\end{array}$ & $\begin{array}{c}\text { Air-dried } \\
\text { wood } \\
(12 \% \text { moisture })\end{array}$ \\
\hline Resistance to static bending & 18.6 & 12.4 \\
Modulus of elasticity & 17.4 & 12.1 \\
Tension at the proportionality & 15.4 & 4.9 \\
limit & & \\
Parallel compression & 25.1 & 9.7 \\
Parallel traction & 27.1 & 13.1 \\
Perpendicular traction & 20.0 & 5.0 \\
Shearing & 39.4 & 9.4 \\
Splitting & 27.5 & 5.9 \\
Janka radial hardness & 14.6 & 24.3 \\
Janka tangential hardness & 12.5 & 3.0 \\
Janka transversal hardness & 11.2 & 5.0 \\
\hline
\end{tabular}

Density behaviour was not similar for the different ages in the base-top direction of the shaft, with the exception of 5 years of age which had homogeneous behavior; the main changes in density along the trunk occurred between logs 1 and 2 at the ages of 7, 9 and 11 years. Therefore, we can notice reduced basic density from the first to the second log, and from the second on the changes were not significant.

Paricá wood is widely used in the plywood industry, however its density is below the average density recommended for the pulp industry. Studies on improvement and forest management are necessary in order to increase the wood density and thus increase the use of this species. In the present work, it was already possible to perceive that an increase in density occurs from 5 to 11 years of age and the homogeneity in this property from a certain shaft height for all ages evaluated.

An increment in the basic density over the years is evidenced in the international literature for several timber species. Since this property is influenced by size, wall thickness and the number or proportion of diverse cells present in the wood, advancement in the years results in increased wall thickness and fiber length, contributing to the increase in density values (Panshin and De Zeeuw, 1980). Therefore, the highest basic wood density values at the base regions in Paricá trees are probably due to mechanical support requirements of the trunk (Sette Junior et al., 2012).

Guler et al. (2007) stated that the most important parameter that influences the contraction of the wood is basic density, since adult wood has higher density, and therefore greater transverse contractions. However, juvenile wood is characterized by its greater longitudinal contraction and smaller contraction in the transverse direction (Bendtsen, 1978; Macalister and Clark, 1991; Oliveira and Silva, 2003). According to Ying et al. (1994), the higher contraction in the longitudinal direction is explained by the larger angle of microfibrils in the S2 layer present in younger wood. Generally, longitudinal contraction is small in more advanced aged woods, a fact observed in Paricá wood at 11 years which had an average of $0.15 \%$ lower in absolute values than those at 5 years [Figure 1 (B)]. However, despite being lower than at other ages, the contraction value at the age of 11 years can still be considered high.

On average, the peripheral region of the shaft had the smallest longitudinal contraction in relation to pith, and also greater homogeneity of this property throughout the trunk, while the lowest variation for the tangential contraction was found in the region near the pith. Because of their greater longitudinal shrinkage, the spinal region of Paricá wood may have higher rates of warping and splitting when subjected to different relative humidity conditions (Oliveira and Silva, 2003).

In general, wood with low anisotropic factor ( $\mathrm{T} / \mathrm{R}$ ratio) are considered stable, meaning with values close to 1 . The mean of the four ages was 1.95 , considered normal according to the classification of Durlo and Marchiori (1992), and lower than those normally found for eucalyptus planted in Brazil at similar ages to those evaluated in this study. This fact contributes to the feasibility of using Paricá wood as a solid product, where high stress is not required due to its low mechanical resistance, as in frames, baseboards, matches and small objects, among others.

\subsection{Mechanical properties}

The resistance values to parallel compression and perpendicular traction to the fibers ( $12 \%$ moisture) of Paricá wood at 11 years were similar to the mean values of 27 and 1.55 MPa, respectively, found for the 10year-old wood of the species coming from the state of Pará (Almeida et al., 2013). However, this same relationship was not found for shearing resistances (8 MPa) and parallel traction to the fibers (49 $\mathrm{MPa})$,

Revista Árvore. 2018;42(1):e420101 
which were higher and lower than the mean observed in the present study. Paricá wood had low values of parallel compressive (22.7 MPa) and shearing strength (5.3 MPa), and low modulus of elasticity (5.811 MPa) in relation to Brazilian mahogany wood [Swietenia macrophylla (46.7; 8.5 and $10.342 \mathrm{MPa}$, respectively)] and to teak [Tectona grandis $(58.0 ; 13.0$ and 10.687 MPa, respectively)] (Kretschmann, 2010).

As age increased, an increase in the mechanical strength of the Paricá wood was also observed, except for the tension in the proportionality limit (green), perpendicular traction (air-dried) and Janka radial hardness (green), tangential hardness (green and airdried) and transverse hardness (green), which presented similar values among the ages. Another exception occurred for the age of 9 years which had a lower basic density and consequently lower resistance in some mechanical properties. Despite the proximity of the sampled trees' growth sites, some uncontrolled external factor probably occurred which led to the reduction of these density values.

The reduction of resistance in the base-top direction, meaning from $\log 1$ to 3 , occurred in the following manner in descending order: resistance to parallel traction (green) $=29.8 \%$; resistance to Janka radial hardness (green) $=20.9 \%$; resistance to splitting $($ green $)=20.5 \%$ and resistance to shearing (air-dried) $=16.7 \%$. The base log presented the highest average values of mechanical resistance, probably due to its higher density. However, a sequential reduction in the mechanical strength values was not observed in the following logs, meaning that similar values occurred in logs 2 and 3, which may also have occurred due to the density variation pattern along the trunk of the tree.

In a few situations (4), the base-top position affected the mechanical properties of the wood. This is advantageous for the industrial sector, since the mechanical resistance of products manufactured with Paricá wood of different heights in the tree possibly will not present great variations, resulting in more homogeneous products regarding their mechanical behavior.

Considering an overall average of the properties of the four ages studied, superiority in the values in air-dried samples in relation to the wet samples in ascending order were: proportionality limit $=31.1 \%$; resistance to parallel compression of the fibers $=22.9 \%$; resistance to perpendicular traction $=22.8 \%$; resistance to static bending $=22.4 \%$; resistance to Janka transversal hardness $=19.1 \%$; modulus of elasticity $=11.8 \%$; resistance to Janka tangential hardness $=11.1 \%$; and resistance to parallel traction $=10.0 \%$. Wood resistance to shearing and splitting and to Janka radial hardness presented similar average values for both moisture conditions, meaning that moisture did not affect these mechanical properties when considering the general mean values for ages. The highest and lowest increase in mechanical properties due to the reduction of wood moisture was respectively observed for the proportionality limit and resistance to parallel traction. Motta (2011) observed an increase of 40 and $38 \%$ in the resistance to perpendicular compression and the perpendicular traction of Teak wood fibers (15 years) with moisture reduction.

According to Farmer's classification (1972), the parallel compression strength of Paricá wood is considered very low in the green state, and low in the air-dried state. The resistance to static bending is very low for both the green state and the air-dried state; an expected fact due to its low basic density.

Resistance to shearing and to Janka transversal hardness were the properties that presented the greatest and the lowest value increases from age 5 to age 11 in wet samples, respectively. For the air dried samples' properties, the greatest and the lowest increase of resistance were observed for Janka radial and tangential hardness, respectively, demonstrating a difference in their behavior with the increase of age.

\section{CONCLUSION}

The basic density of the Paricá was reduced in the base-top direction, and no difference was found between the radial positions. An increase in this property was observed with increasing age, however, on average the basic density of this wood was characterized as low. The region close to the bark showed less longitudinal contraction and also greater homogeneity of this property in the trunk, while the lowest variation for the tangential contraction was found in the region near the pith. Paricá wood contraction was characterized as low.

The mechanical strengths are generally low, with the better results coming from the log positioned at the base of the Paricá tree and at more advanced ages. The effect of moisture is most evident on the properties of compressive strength parallel to fibers.

Revista Árvore. 2018;42(1):e420101 
Paricá wood has low linear and volumetric contractions, although there is a need for studies with the purpose of increasing wood density so that the species can be used in new products and markets.

\section{ACKNOWLEDGEMENTS}

To the National Council of Scientific and Technological Development - CNPq (Brazil) for the financial support; to Luciano Zaneti, Alessandro Lechinoski, Silvano D'Agnoluzzo for supplying the material; to the carpenter Mr. José Cardoso Moreira; and to the forest engineers Roberta Forsani and Pedro Gustavo Ulisses Frederico.

\section{REFERENCES}

Almeida DH, Cavalheiro RS, Scaliante RM, Christoforo AL, Calil Junior C, Lahr FAR. Full characterization of strength properties of Schizolobium amazonicum wood for timber structures. International Journal of Engineering \& Technology.2013;13(6):93-6.

Associação Brasileira de Normas Técnicas ABNT. NBR 7190: Projeto de estruturas de madeira. Rio de Janeiro: 1997.

Bendtsen B A. Properties of wood from improved and intensively managed trees. Forest Products Journal. 1978;28:61-71.

Cobas AC, Area MC, Monteoliva S. Transición de madera juvenil a madura en un clon de Populus deltoides implantado en Buenos Aires Argentina. Maderas, Ciencia y Tecnología. 2013;15(2):223-34.

Dünisch O, Richter H, Koch G. Wood properties of juvenile and mature heartwood in Robinia pseudoacacia L. Wood Science and Technology. 2010;44:301-13.

Durlo MA, Marchiori JNC. Tecnologia da madeira: retratibilidade. Santa Maria: CEPEF/FATEC; 1992. v.33.

Farmer RH. Handbook of hardwoods. $2^{\text {nd }}$. ed. London: Her Majesty'S Stationery Office, 1972. 243p.

Guler C, Copur Y, Akgul M, Buyuksari U. Some chemical, physical and mechanical proprieties of juvenile wood from Black pine (Pinus nigra

Revista Árvore. 2018;42(1):e420101
Arnold) plantations. Journal of Applied Sciences. 2007;7:755-8.

Indústria Brasileira de Árvores - IBÁ. Relatório anual 2016. Brasília: 2016. 100p.

Kretschmann DE. Mechanical properties of wood. In: Forest Products Laboratory. Organizadores. Wood handbook: wood as an engineering material. Madison: U.S. Department of Agriculture, Forest Service, Forest Products Laboratory; 2010. p.100-45.

Lara Palma HÁ, Ballarin AW. Propriedades de contração na madeira juvenil e adulta de Pinus taeda L. Scientia Forestalis. 2003(64):13-22.

Macalister R, Clark A. Effect of geographic localization and seed source on bending properties of juvenile and mature loblolly pine. Forest Products Journal. 1991;41:39-41.

Motta JPM. Propriedades tecnológicas da madeira de Tectona grandis 1.f. proveniente do vale do rio doce, Minas Gerais [dissertação]. Jerônimo Monteiro: Universidade Federal do Espírito Santo; 2011.

Oliveira JTS, Silva JC. Variação radial da retratibilidade e densidade básica da madeira de Eucalyptus saligna Sm. Revista Árvore. 2003;27:381-5.

Panshin AJ, De Zeeuw C. Textbook of wood technology. $4^{\text {th }}$.ed. New York: Mc Graw Hill Book Company; 1980.

Peres ML, Gatto DA, Stangerlin DM, Calegari L, Beltrame R, Haselein CR. et al. Idade de segregação do lenho juvenil e adulto pela variação da massa específica de açoita-cavalo. Ciência Rural. 2012;42(9)1596-602.

Sette Junior CR. Oliveira IR, Tomazello Filho M, Yamaji FM, Laclau JP. Efeito da idade e posição de amostragem na densidade e características anatômicas da madeira de Eucalyptus grandis. Revista Árvore. 2012;36(6):1183-90.

Silva JJN, Cardoso GV, Silva Júnior FG, Stangerlin DM. Caracterização tecnológica da madeira de Schizolobium amazonicum para a produção de celulose Kraft. Ciência da Madeira. 2013;4(1):33-45. 
Vidaurre GB, Vital BR, Zaneti L, Colli A, Naumann R. Paricá uma espécie promissora. Revista da Madeira. 2006;97:2006. Disponível em: http:// www.remade.com.br/br/

revistadamadeira materia.php?num $=924 \&$ subject $=\mathrm{E} \% 20$ mais. \&title $=$ Paric $\%$ E1\%20uma $\% 20$ esp $\%$ E9cie $\% 20$ promissora

Vidaurre G, Lombardi LR, Oliveira JTS, Arantes MDC. Lenho juvenil e adulto e as propriedades da madeira. Floresta e Ambiente.2011;18(3):469-80.
Yeh T, Braun JLG, Ldfarb B, Chang H, Kadla JF. Morphological and chemical variations between juvenile wood, mature wood and compression wood of loblolly pine (Pinus taeda L.). Holzforchung.2006;60:1-8.

Ying L, Kretschmann D, Bendtsen B.

Longitudinal shrinkage in fast-grown loblolly pine plantation wood. Forest Production Journal. 1994;44:58-62. 